\title{
O LEGADO DA REMEMORAÇÃO: TRAÇOS E VESTíGIOS MEMORIAIS NAS AMÉRICAS
}

\author{
The LeGaCy of Rememoration: Traces and Memory \\ VeSTIGES IN THE AMERICAS
}

Sandra Regina Goulart Almeida

Universidade Federal de Minas Gerais

Belo Horizonte, MG, Brasil

Palavras-chave: Memória, traço, rastro, vestígios.

Keywords: Memory, trace, mark, vestiges.

Palabras-clave: Memoria, trazo, rastro, vestigio.

* (MORRISON, Toni. Beloved. New York: Plume, 1988: 35-36.)

\section{Resumo}

À luz da temática dos rastros e da memória como herança familiar, percurso individual e legado histórico, o trabalho discute romances de escritoras contemporâneas das Américas, a partir da articulação do conceito de "rememoraçâao" de Toni Morrison e das teorizaçôes sobre a noção de traço e o rastro, segundo Freud, Ricouer, Benjamin, Derrida e Spivak.

\begin{abstract}
Based on the theme of traces and memory as family heritage, individual trajectory, and historical legacy, this work analyzes novels by contemporary women writers from the Americas with a view to articulating the concept of rememoration by Toni Morrison and the theorizations about the notion of trace by Freud, Ricouer, Benjamin, Derrida and Spivak.
\end{abstract}

\begin{abstract}
Resumen
A la luz del tema de los rastros y de la memoria como herencia familiar, recorrido individual y legado histórico, el trabajo analiza novelas de escritoras contemporáneas de las Américas, a partir de la articulación del concepto de "rememoración" de Toni Morrison y de las teorizaciones sobre las nociones de trazo y rastro de Freud, Ricouer, Benjamin, Derrida y Spivak.
\end{abstract}

I was talking about time. It's so hard for me to believe in it. Some things go. Some things just stay.

I used to think it was my rememory. You know. Some things you forget. Other things you never do. But it is not. Places, places are still there. If a house burns down, it's gone, but the place - the picture of it - stays, and not just in my rememory, but out there, in the world. What I remember is picture floating around out there outside my head.

I mean, even if I don't think it, even if I die, the picture of what I did, or knew, or saw is still out there. Right in the place where it happened.* 
A epígrafe que abre este trabalho remete a uma cena do romance Beloved [Amada] (1988), de Toni Morrison, na qual a personagem Sethe Gerner reflete sobre o poder da memória e o sentido de "rememoração", termo que aparece insistentemente na ficção da escritora afro-americana. $\mathrm{O}$ conceito aqui evocado se refere tanto ao ato de lembrança da memória quanto ao retorno incessante das reminiscências do passado, em especial da história, da vivência e do trauma da escravidão. Nesse significativo diálogo que trava com a filha Denver, que diferentemente de sua mãe e irmãos nasceu livre, a personagem de Morrison fala da "rememória" não apenas para se referir ao trabalho de resgate dessa memória lacunar, mas também para evocar as experiências individuais de sofrimento de um povo que continuam a existir nos lugares onde ocorreram por força dos vestígios memoriais de geraçóes ancestrais.

A rememoração revela-se ainda como uma potente forma de compreender como as experiências da memória coletiva e do legado histórico de outrem podem ser compartilhadas pela comunidade, apontando para a ligação intrínseca entre memória individual e memória social. É o que Sethe insinua ao continuar sua reflexão: "Um dia você vai andar por uma estrada e ouvir alguma coisa ou ver alguma coisa acontecendo. E você pensa que é você pensando isso. Uma imagem de pensamento. Mas não. É quando você encontra uma rememória que pertence a uma outra pessoa. ${ }^{1 *}$ Essa "rememória" que pertence a um outro, essa experiência da ordem da alteridade, torna-se transmissível àqueles cujas vivências são perpassadas por episódios igualmente emblemáticos por meio de marcas deixadas para serem desveladas e trilhadas por outros.

$\mathrm{Na}$ leitura que Homi Bhabha faz do romance de Toni Morrison, o "ato da 'rememoração' (seu conceito de recriação da memória popular) transforma o presente da enunciação narrativa no memorial obsessivo do que foi excluído, amputado, despejado, e que por esta mesma razão se torna um espaço unheimlich para a negociação da identidade e da história”. ${ }^{*}$ Esse espaço unheimlich, no dizer de

\footnotetext{
${ }^{1}$ São minhas esta e as demais traduções das citaçóes do romance utilizadas neste trabalho. No original: "Someday you be walking down the road and you hear something or see something going on. So dear. And you think it's you thinking it up. A thought picture. But no. It's when you bump into a rememory that belongs to someone else".
}

*(Ibidem: 36 .)

* (BHABHA, Homi. O local da cultura. Trad. Myriam Ávila, Eliana Reis e Gláucia Gonçalves. Belo Horizonte: Editora UFMG, 2007: 274-275.) 
Bhabha ao evocar Freud, esse espaço no qual se situa o que é estranho, que deveria ter sido mantido em segredo e ocultado, mas que aflora como se não pudesse ser escondido ou recalcado se transforma em um "memorial" no sentido etimológico do termo como "aquilo que faz lembrar" ou aquilo que se reveste como um monumento de algo que se reconstrói e se rememora de um passado a ser continuamente visitado. No processo espiralar de reconstruçáo de uma memória coletiva e imaginada dá-se vida ao que poderia supor-se escondido, obscurecido e mesmo esquecido nos espaços lacunares da memória. É essa imperativa tarefa de recuperação de um passado traumático da história de um povo bem como de uma experiência individual singular que Morrison revisita por meio da narrativa de Sethe, isto é, como memórias e vivências interditas que insistem em aflorar. O infanticídio indizível perpetrado pela personagem somente torna-se inteligível pela narração dessa rememoração que transforma o recalcado em memorial eterno de luto da perda inaceitável.

O trabalho incessante de rememoração sobre o qual discorre a autora neste romance suscita ainda imbricamentos relevantes. Em primeiro lugar, essa memória não se configura de forma acabada e desvelada, mas se encontra camuflada por meio de imagens cuja existência é percebida meramente em lampejos, rastros, traços e vestígios memoriais. Em segundo, essa memória não é apenas coletiva, mas também individual e, por isso, aponta para a singularidade dessa experiência que é também da ordem de um necessário relacionamento ético e de responsabilidade para com um outro. E, por último, o ato de narrar, a construção de uma narração, tornase fundamental como processo que confere significância aos relatos memoriais, que permite o trilhamento de vestígios que, de outra forma, estariam relegados ao esquecimento.

Proponho neste trabalho abordar essas três questóes à luz de dois romances de escritoras contemporâneas das Américas - Toni Morrison e Dionne Brand -, pois, como lembra Zilá Bernd, "a investigação sobre a ficção romanesca do final do século XX e princípios dos XXI é o lugar privilegiado de memória coletiva, permitindo a decodificação das escolhas que as comunidades novas das

* (BERND, Zilá. Vestígios memoriais: fecundando as literaturas das Américas. Conexão Letras, n. 6, 2011:10.) Américas fizeram e fazem em relação a suas ancestralidades".* $\mathrm{O}$ fazer literário dessas escritoras, modulado pelo ritmo da memória, é, assim, marcado pelo legado histórico da travessia pelo Atlântico em direção às Américas, espaço emblemático de rememora- 
ção ancestral. Nesse trasladar, incerto e inglório pelos caminhos da memória e também da escrita, essas escritoras tecem os fios da narrativa memorial que resgata a história dos povos africanos em seu contínuo deslocamento da África, atravessando o oceano Atlântico pela "Passagem do Meio" [Middle Passage] em direção à África e ao Caribe, em função do contexto histórico do tráfico de escravos que deu suporte à lavoura de cana nos países colonizados. Uma vez fazendo essa travessia, percorrendo esse portal na África que marca a saída dos africanos em direção a outras terras, não há volta, apenas a contínua experiência do trânsito e da mobilidade.

No livro de ensaios A Map to the Door of No Return, a escritora caribenho-canadense Dionne Brand remete à passagem por esse portal emblemático como uma experiência desoladora, pois "foi o lugar da criação dos negros na diáspora do novo mundo ao mesmo tempo em que significa o fim de começos rastreáveis". ${ }^{2 *}$ Se, por um lado, as narrativas aqui analisadas se prendem a relatos de resgate de começos que não podem facilmente ser traçados, rastreáveis ou localizáveis (porque o "traço" não é uma marca referencial, como veremos); por outro, permanecem inquietantemente atreladas à urgência de rememorar não apenas esse começo, mas toda uma ancestralidade silenciada que insiste em brotar de uma memória imagética recorrente que recusa o interdito e aflora como o estranho que não quer (ou pode) calar. Essas narrativas, contadas por vozes marcadamente femininas, são igualmente perpassadas pela força de vestígios de uma herança feminina e materna que configura de forma candente os rastros memoriais.

\section{Traços da memória: percursos teóricos}

A memória, afirma Paul Ricouer, que recorre aos clássicos ao trilhar um itinerário histórico do termo, refere-se a uma aporia, pois remete ambiguamente à ausência de uma presença ou à "presença de uma coisa ausente, marcada pelo selo da anterioridade”.* Fazendo uma observação correlata, Walter Moser nos lembra que anamnese, termo advindo do grego, cujo significado se atrela à reminiscência, à recordação, ao ato de trazer algo à memória, con-

\footnotetext{
${ }^{2}$ Todas as traduçóes da obra de Diana Brand são de minha autoria. No original: "In some desolate sense it was the creation place of Blacks in the New World Diaspora at the same time that it signified the end of traceable beginnings."
}

* (BRAND, Dionne. A Map to the Door of No Return. Toronto: Vintage Canada, 2002: 5. Grifo meu.)

* (RICOUER, Paul. A memória, a história, o esquecimento. Trad. Alain François et.al. Campinas: Unicamp, 2007: 18.) 
* (MOSER, Walter. Estratégias memorialísticas nos filmes comerciais de (an)amnésia. In: BAHIA, Márcio; MOSER, Walter; PEREIRA, Maria Antonieta (Org.). Filmes de (an)amnésia: memória e esquecimento no cinema comercial contemporâneo. Belo Horizonte: FALE/UFMG/A tela e o texto, 2009: 18.)

* (RICOEUR, Paul, op. cit., 2007: 27.)

* (GAGNEBIN, Jeanne Marie. Apagar os rastros, recoIher os restos. In: SEDLMAYER, Sabrina; GINZBURG, Jaime. (Org.). Walter Benjamin: rastro, aura e história. Belo Horizonte: Editora UFMG, 2012: 28.)

* (GAGNEBIN, Jeanne Marie. O rastro e a cicatriz: metáforas da memória. Pro -posições, v. 13, n. 3 (39), 2002: 130.) tém em seu próprio bojo a noção de esquecimento e de perda da memória (pela junção de "an" e "amnésia").*

$\mathrm{Na}$ esteira de Ricouer, pode-se argumentar que se "a memória é do passado", como diria Aristóteles (citado pelo crítico francês), ela, por um lado, está inevitavelmente associada à imaginação trazendo consigo desde a origem "o cunho da suspeita"* e, por outro lado, remete ao trabalho do historiador que perscruta rastros escritos e arquivados em busca de um passado histórico, por vezes a ser revisitado. São, pois, esses dois aspectos basilares que me interessa abordar neste trabalho.

Refletir sobre a literatura cujo eixo fulcral é a memória nos leva à articulação de conceitos operatórios que se desenrolam sob a égide dos rastros, traços, vestígios como chaves de leitura. A memória e os vocábulos a ela associados operam por meio de uma dialética complementar na qual palavras aparentemente opostas se interligam constitutivamente: ausência/presença, memória/esquecimento. Seguindo a mesma trilha, o notório conceito de Spur, utilizado extensivamente por Walter Benjamin, termo que recebe várias traduçôes em português (como rastro, traço, vestígio, resto, marca, entre outros), ${ }^{3}$ aponta para uma questão temporal e para a interpretação do passado, bem como para seu caráter igualmente paradoxal que, como observa Jeanne Marie Gagnebin, "remete à questão da manutenção ou apagamento do passado, isto é à vontade de deixar marcas, até monumentos de uma existência humana fugidia, de um lado, e às estratégias de conservação ou de aniquilamento do passado, do outro".* O rastro (ou traço, como procuro aqui explorar) é, portanto, um signo não intencional, pois não pode se controlado pela consciência, como nos lembra Freud. Nas palavras de Gagnebin, "rastros não são criados - como o são outros signos culturais e linguísticos -, mas, sim deixados ou esquecidos".*

\footnotetext{
${ }^{3}$ Para uma discussão sobre a tradução do termo em Benjamin, ver o artigo de Georg Otte, "Vestígios da experiência e índices da modernidade: traços de uma distinção oculta em Walter Benjamin". Segundo o autor a variação da tradução do termo tanto em português como em outras línguas causa certo problema, já que a recorrência e mesmo a repetição do termo Spur tem um significado especial nos escritos de Benjamin fazendo com que "se cristalize na superfície do fluxo verbal, ganhando um status terminológico" (OTTE, Georg. Vestígios da experiência e índices da modernidade: traços de uma distinção oculta em Walter Benjamin. In: SEDLMAYER, Sabrina; GINZBURG, Jaime. (Org.). Walter Benjamin: rastro, aura e história. Belo Horizonte: Editora UFMG, 2012: 71).
} 
O processo de seguir rastros é comparado ao trabalho do arqueólogo, metáfora evocada tanto por Benjamin quanto Freud, para se referir ao processo de rememoração e reconstrução, além de aludir ao já mencionado espaço unheimlich de irrupção daquilo que é reprimido ou escamoteado, conforme evocado por Bhabha, na esteira de Freud. Se o ato de seguir rastros, então, remete a um trabalho de busca e de investigação, essa ação pode se referir não somente ao trabalho do arqueólogo, mas também ao do detetive que, como aponta Lévinas, ao analisar o rastro como um signo polissêmico, "examina como signo revelador tudo o que ficou marcado nos lugares do crime, a obra voluntária ou involuntária do criminoso". Assim, o imperativo de seguir rastros como ação detetivesca pode implicar também seu apagamento, pois "sua significância original desenha-se na marca impressa que deixa, por exemplo, aquele que quis apagar seus rastros, no cuidado de realizar um crime perfeito" . ${ }^{4 *}$ Daí a relevância da noção de rastro, em seu sentido estendido de traço, trilha, pista, vestígios, resíduos, para a literatura criminal.

Em carta a Adorno, em 1938, Benjamin discorre sobre a associação do conceito de rastro ao romance policial, mais especificamente à obra de Edgar Allan Poe, estabelecendo uma conexão significativa entre o detetive e o artista. Com bem coloca Jaime Ginzburg, o "processo criativo se desenvolve, no campo do romance policial, com a busca por uma solução, uma verdade, que revela a cada vez uma face da disponibilidade para o crime".* O apagamento de rastros em Benjamin remete ainda, como lembra Gagnebin, à condição de clandestinidade e ilegalidade do refugiado, exilado ou emigrante.* É na referência ao emblemático poema de Bertold Brecht, de Cartilha para citadinos, que Benjamin constrói essa relação ao criticar a necessidade burguesa de deixar rastros de sua existência:

Esses vestígios [num quarto burguês] são os bibelôs sobre as prateleiras, as franjas ao pé das poltronas, as cortinas transparentes atrás das janelas, o guarda-fogo diante da lareira. Uma bela frase de Brecht pode ajudar-nos a compreender o que está em jogo: "Apaguem os rastros!" diz o estribilho do primeiro poema da Cartilha para citadinos. Essa atitude é a oposta da que é determinada pelo hábito, num salão burguês.*

Essa referência à tentativa de a burguesia "buscar uma compensação pelo desaparecimento de vestígios da vida privada na cidade

\footnotetext{
${ }^{4}$ Cito do texto de Gagnebin com tradução ligeiramente modificada pela autora (2012: 31).
}

* (LÉVINAS, Emmanuel. Humanismo do outro homem. Trad. Pergentino Pivato. Petrópolis: Vozes, 1993 : 75-76.)

* (GINZBURG, Jaime. A interpretação do rastro em Walter Benjamin. In: SEDLMAYER, Sabrina; GINZBURG, Jaime. (Org.). Walter Benjamin: rastro, aura e história. Belo Horizonte: Editora UFMG, 2012: 113.) * (GAGNEBIN, J. M. op. cit., 2012: 28.)

* (BENJAMIN, Walter. Experiência e pobreza. In: Magia e técnica, arte e política: ensaios sobre literatura e história da cultura. Trad. Sergio Paulo Rouanet. São Paulo: Brasiliense, 1994: 118.) 
* (BENJAMIN, Walter. Paris do segundo império. In: Charles Baudelaire: um lírico no auge do capitalismo. Trad. Hemerson Alves Baptista e José Carlos Martins Barbosa. São Paulo: Brasiliense, 1989: 43.)

* (DeRridA, Jacques. Posições. Trad. Tomás Tadeu da Silva. Belo Horizonte: Autêntica, 2001: 32.)

* (DERRIDA, Jacques. Gramatologia. Trad. Miriam Schnaiderman e Renato Janine Ribeiro. São Paulo: Perspectiva/Edusp, 1973: 79-80.)

* (Ibidem: 104.)

*(DERRIDA, Jacques. O monolinguismo do outro ou a prótese de origem. Trad. Fernanda Bernardo. Porto: Campo das Letras, 2001: 92.) grande", ao qual remete Benjamin em outro texto, ${ }^{*}$ em oposição ao clamor do poema de Brecht, confere ao apagamento de rastros um significado outro ao rejeitar a premissa burguesa de marcar um espaço, colocando em relevo as condiçóes de vários sujeitos deslocados e cujos vestígios são apagados ou por eles mesmos (como estratégia de sobrevivência) ou por outrem (que lhes nega tal direito pela condição de marginalidade ao sistema). Esse viés nos permite estender o conceito de rastro em direçáo a outros questionamentos relevantes para se analisar os romances aqui abordados.

Seguindo a teorização de Benjamin, Jacques Derrida parece também estabelecer uma relação intrínseca entre o conceito de traço ou rastro $(\text { la trace })^{5}$ e a situaçáo de exilados e migrantes, sujeitos marginalizados, estrangeiros e estranhos na língua do outro. Seu conceito de rastro, imbricado na teorização sobre a diferência (différance), se articula a partir da premissa de que cada elemento se constitui "a partir do rastro dos outros elementos da cadeia ou do sistema", pois "não existe, em toda parte, a não ser diferenças e rastros de rastros", ${ }^{*}$ sendo que textos se configuram como "cadeias e sistemas de rastros".* Assim, o rastro determina um movimento de "propensáo e retençáo", ${ }^{*}$ como marcas do passado emoldurando o futuro, mas deslocando-se ininterrupta e compulsivamente para a anamnese:

A ruptura com a tradição, o desenraizamento, a inacessibilidade das histórias, a amnésia, a indecifrabilidade, etc., tudo isto desencadeia a pulsão genealógica, o desejo do idioma, o movimento compulsivo para a anamnese, o amor devastador pelo interdito.*

O termo "traço" é também utilizado recorrentemente por Gayatri Chakravorty Spivak (igualmente com o sentido de rastro, pista, trilha, vestígio, marca) na esteira da teorização de Derrida, que segue, como vimos, o lastro de teorias linguísticas e psicanalíticas. Segundo Spivak,

\footnotetext{
${ }^{5}$ Os tradutores brasileiros da Gramatologia de Derrida utilizam o termo rastro ao invés de traço para traduzirem o termo la trace utilizado pelo autor, argumentando que "o substantivo francês trace náo deve ser confundido nem com trait (traço) nem com tracé (traçado), pois se refere a marcas deixadas por uma ação ou pela passagem de um ser ou objeto" (DERRIDA, Jacques. Gramatologia. Trad. Miriam Schnaiderman e Renato Janine Ribeiro. São Paulo: Perspectiva/Edusp, 1973: 22). No entanto, uma das acepçóes do termo, de acordo com o Dicionário eletrônico Houaiss da língua portuguesa, é justamente o sentido figurado daquilo que restou como vestígios, rastros, sinais. Nesse sentido, justifica-se, como também o faz Spivak adiante, o uso do termo conforme a escolha de Derrida.
} 
Derrida, então, dá o nome de traço ao papel exercido pelo outro radical dentro da estrutura da diferença que é o signo. (Mantenho o termo traço [trace] em minha traduçáo porque parece ter o mesmo sentido que o termo usado por Derrida; o leitor deve se lembrar de pelo menos as palavras rastro, e mesmo pista, contidas no termo francês). A despeito de si mesma, a linguística saussureana reconhece a estrutura do signo como uma estrutura-traço. E a psicanálise de Freud, de certa forma a despeito de si mesma, reconhece a própria estrutura da experiência como um traço, e não uma estrutura-presença.*

Para Freud, o traço é aquilo que "sobra ou fica fora e deixa uma marca" que "desenha trilhamentos", enquanto que para Derrida, o traço "é a diferença impalpável e invisível entre os trilhamentos".* A responsabilidade a esse "traço" do outro, isto é, à marca, aos vestígios e rastros desse outro no contexto social, cultural e histórico (àquilo que ele traz consigo sem às vezes perceber) aqui se refere à singularidade ética, isto é, a um relacionamento que deveria ser individual e íntimo, como um acolhimento, "um abraço, um ato de amor" , cuja ação é efetuada em resposta a um chamado ao qual se deve uma resposta e uma escuta num movimento dialógico entre o eu e o outro. É nesse sentido que a teórica indiana propóe pensar em sua teorização sobre a tradução em uma proposta de responsabilidade ao traço do outro: "devo sugerir que se pense no traço ao invés de se pensar na tradução levada a cabo, concluída: o traço do outro, o traço da história, e mesmo os traços culturais”.*

Atrelar a categoria do traço/rastro ao processo tradutório que coloca o outro em cena e convida à responsabilidade ética suscita ainda a questão do posicionamento do sujeito que intermedia esse contato, esteja ele representado na figura do tradutor ou do narrador e nos leva a refletir sobre o ato de narrar como processo de trilhamento no qual cada vestígio ou pista conduz a um rastreamento de memórias e a um resgate do passado. Como lembra Benjamin, o narrador "pode recorrer ao acervo de toda uma vida (uma vida que não inclui apenas a própria experiência, mas em grande parte a experiência alheia. $\mathrm{O}$ narrador assimila à sua substância mais íntima aquilo que sabe por ouvir dizer)" * São os rastros de sua própria memória ou de outrem que concerne o trabalho do narrador: "Assim se imprime na narrativa a marca do narrador, como a mão do oleiro na argila do vaso. [...] Assim, seus vestígios estão presentes de muitas maneiras nas coisas narradas, seja na qualidade de quem as viveu, seja na qualidade de quem as relata”*
* (SPIVAK, Gayatri Chakravorty. Translator's Preface. In: DERRIDA, Jacques. Of Grammatology. Baltimore and London: The Johns Hopkins University Press, 1976: xvii.)

* (REGO, Cláudia de Morais. Traço, letra, escrita - Freud, Derrida, Lacan. Rio de Janeiro: 7Letras, 2006: 15.)

* (DERRIDA, Jacques. Of Grammatology. Baltimore and London: The Johns Hopkins University Press, 1976: 180.)

* (SPIVAK, Gayatri Chakravorty. Translator's Preface and Afterword to Mahasweta Devi, Imaginary Maps. In: . The Spivak Reader.

New York and London: Routledge, 1996: 269.)

* (SPIVAK, Gayatri Chakravorty. Translation into English. In: BERMANN, Sandra; WOOD, Michael. Nation, Language and the Ethics of Translation. Princeton: Princeton University Press, 2005: 105.)

* (BENJAMIN, Walter. O narrador: considerações sobre a obra de Nikolai Leskov. In: _. Magia e técnica, arte e política: ensaios sobre literatura e história da cultura. Trad. Sergio Paulo Rouanet. São Paulo: Brasiliense, 1994: 221.)

* (Ibidem: 205.) 
* (DERRIDA, Jacques. Of Grammatology. Baltimore and London: The Johns Hopkins University Press, 1976: 190.)

* (GINZBURG, Jaime. A interpretação do rastro em Walter Benjamin. In: SEDLMAYER, Sabrina; GINZBURG, Jaime. (Org.). Walter Benjamin: rastro, aura e história. Belo Horizonte: Editora UFMG, 2012: 125-127.) * (Ibidem: 127.)

* (BRAND, Dionne. At the Full and Change of the Moon. Toronto: Vintage Canada, 1999.)

* (MORRISON, Toni. A Mercy. New York: Alfred A. Knopf, 2008.)

* (GILROY, Paul. The Black Atlantic: Modernity and Double Consciousness. Cambridge, MA: Harvard University Press, 1993.)
Para Derrida, quando a "escrita entra em cena, o traço transforma-se em grama e o campo do trilhamento em espaço cifrado”.* $\mathrm{O}$ ato de narrar encena um espaço de memórias em meio a uma topografia de traços, mas também desvela a inerente característica dos rastros, isto é, a ambiguidade constitutiva de evocar a presença de uma ausência. Nesse sentido, como bem adverte Ginzburg, a partir da perspectiva benjaminiana, toda narrativa que evoca a memória se ocupa também de esquecimentos, de lacunas e incertezas; os rastros remetem necessariamente à "categoria da fantasmagoria" e, por isso, náo se pode operar com a expectativa de "totalizaçôes conclusivas".*

É esse ato de narrar que segue os rastros da memória em busca daquilo que foi esquecido ou reprimido, como uma imagem fantasmagórica, que tratam os romances aqui analisados. São escritas da perda, para usar um termo de Ginzburg, ${ }^{*}$ mas são também narrativas de vestígios memoriais que resgatam estórias apagadas e personagens esquecidas, redesenham a história a contrapelo e inserem vozes obliteradas no tecido lacunar da memória individual e coletiva. $\mathrm{O}$ ato de rememoração, para retomar o apropriado tropo de Toni Morrison, vislumbra-se por meio de uma cartografia de trilhamentos construindo um espaço da memória pelo processo de narrar tanto o dito quanto o interdito. Seguindo de forma similar o mote de Beloved, que se constrói por meio da progressiva narrativa da estória de uma mãe escrava que mata sua própria filha para livrá-la da escravidão, tanto At the Full and Change of the Moon* quanto $A$ Mercy ${ }^{*}$ também partem da narração, do relato de um traslado em busca de algo que serve de gatilho para a memória, bem como de um crime que somente aos poucos ou mesmo ao final é revelado. Os leitores seguem então a trilha, os rastros e pistas construídos pela memória de narradores que por vezes mais ocultam do que relatam os detalhes do delito. Os romances se articulam, assim, em torno de três temas recorrentes: o crime, a construção da memória, e o deslocamento - tropos esses intrinsecamente associados aos rastros deixados pelos/as narradores/as para serem trilhados e decifrados. Em ambos os casos, os romances retomam o passado para construírem narrativas que reencenam uma história outra que se constrói à revelia da história oficial sobre a colonização das Américas e o tráfico de escravos pela rota do Atlântico Negro, ao qual se refere Paul Gilroy.* No centro dos romances está a tentativa de resgate das memórias daqueles que viveram na escravi- 
dão ou sofreram traumas cuja marcas consigo carregam através de sucessivas gerações.

Vestígios de uma herança

"I am full of memories for her"*

O romance At the Full and Change of the Moon (1999) recupera uma narrativa que inaugura um momento crucial na história dos trânsitos humanos ao abordar o movimento diaspórico de povos africanos no Caribe. A narrativa abre com o desenho de uma árvore que traça toda a genealogia de uma geração de africanos no Caribe e seus descendentes, desde a matriarca Marie Ursule, escrava morta em 1924, a filha Bola, nascida escrava em 1821 e falecida em 1921, em Culebra Bay, até o relato da segunda Bola, nascida em 1982, e que vive em Culebra Bay. Assim, somos apresentados não apenas à história de um indivíduo, mas à saga de toda uma família, de toda uma linhagem, que é formada pelos descendentes de Marie Ursule, Bola e seus vários filhos espalhados pelos continentes. Ao longo da narrativa temos acesso às vidas de alguns desses descendentes, e, assim, acompanhamos os rastros, os vestígios e as estórias de personagens que se fixam em Culebra Bay e outros que se deslocam para o Canadá, a Europa e a América Latina. As personagens se encontram ligadas não apenas pelo sangue, mas também pela origem marcada pelo trauma da violência, pela tragédia histórica que os marcou e pelo deslocamento sucessivo. É, pois, uma narrativa que discorre sobre a memória transmitida a essa geração de sujeitos desarraigados, desde a primeira Bola, a filha que Marie Ursule, poupa da morte, até a segunda Bola, que nasce no Canadá, mas acaba por ser mandada de volta a Culebra Bay.

Diferentemente do que ocorre em Beloved, que relata o infanticídio perpetrado pela mãe como forma de salvar a filha da escravidão, Marie Ursule salva a filha da morte no suicídio coletivo por ela arquitetado como forma de revolta contra a escravidão. É esse o crime cometido por Marie Ursule e que tem como consequência a fuga e o isolamento da filha Bola, que cresce sem qualquer convívio com sua família e comunidade, já que ela era a única que restou. A enorme prole e a dispersão de seus filhos não tem outro objetivo senão preservá-los da tragédia e do trauma herdados, de modo que não pudessem se juntar todos no mesmo lugar e sofrer o mesmo destino funesto que sua mãe e, em certa medida, ela própria
* (BRAND, Dionne. At the Full and Change of the Moon. Toronto: Vintage Canada, 1999: 289.) 
* (BRAND, Dionne. At the Full and Change of the Moon. Toronto: Vintage Canada, 1999: 43.)

* (Ibidem: 44.) sofreram. Deixada aos cuidados de Kamena, que falece a seguir, Bola, em meio aos fantasmas das freiras ursulinas que lhe foram transmitidos pela memória materna, sobrevive sozinha em Culebra Bay e adota para si a tarefa hercúlea de dar vida e origem a uma geração inteira que, de outra forma, seria completamente apagada:

Este lugar é continuamente imaginado. Cada fragmento pertence a uma certa memória - um sonho, uma versão - cada fragmento guardado descuidado e intimamente. É por isso que ele ainda existe. Nada acontece aqui. Nada extraordinário para sua época. Duas freiras eram donas de escravos como qualquer padre ou explorador ou colonizador no Novo Mundo. São os outros, os que elas mantinham ali que guardam a memória, que imaginam constantemente onde eles poderiam estar. São eles que mantêm os detalhes vivos e em estado bruto como se tivessem ocorrido ontem. ${ }^{6 *}$

$\mathrm{Na}$ verdade, não se sabe ao certo nada sobre as freiras ursulinas; sua existência se resume ao espaço da memória e ao ato de narrar, pois são apenas "uma estória que Marie Ursule um dia contou para Bola”. ${ }^{7 *}$ Mesmo Kamena, que recebe de Marie Ursule a incumbência de levar Bola para Culebra Bay e mantê-la sã e salva, acaba por sucumbir "faminto pelas lembranças", 8 pedindo a Bola que guarde as memórias do passado e de sua herança consigo. $\mathrm{O}$ ato de narrar aqui assume o fardo de reter as memórias; contá-las aos outros equivale a rememorar constantemente um passado histórico que não pode ser apagado. Por isso várias personagens insistem em contar estórias, em passar estórias a outros para serem guardadas da mesma forma que relíquias de família devem necessariamente passar de uma geração a outra.

A memória funciona como o receptáculo da herança materna na diáspora dos vários filhos de Bola. Ao longo da narrativa, estórias são aos poucos relatadas, recontadas por diversos personagens, sob óticas distintas. À estória coletiva construída pelo ato de narrar se juntam fragmentos de relatos individuais através dos tempos que

\footnotetext{
${ }^{6}$ As traduções do romance são de minha autoria. No original: "This place is imagined over and over again. Each fragment belonging to a certain mind - a reverie, a version - each fragment held carelessly or closely. Which is why it still exists. Nothing happened here. Nothing extraordinary for its time. Two nun held slaves like any priest or explorer or settler in the New World. It is the others, the ones they held, who keep the memory, who imagine over and over again where they might be. It is they who keep these details alive and raw like yesterday."

${ }^{7}$ No original: "They are a story Marie Ursule once told Bola".

${ }^{8}$ No original: "starved with remembering. "Hold this for me"
} 
brotam dos espaços mais recônditos da memória que insiste em se fazer lacunar, pois como relata a voz narrativa, "os séculos são locais de esquecimento" "* São estórias de deslocamentos, exílios, errâncias e retornos. Cada filho ou filha reserva uma parte dessa estória, que também é uma história às avessas, contada a contrapelo, que aos poucos é recomposta pela tessitura da narrativa. São estórias narradas por aqueles e aquelas que sobreviveram ao processo de escravatura, à dispersão dos negros pelo Atlântico e, a seguir, ao processo de rediasporização nas Américas. Aqui a memória tem ainda uma funçáo histórica primordial ao recolher os relatos daqueles que estiveram sempre às margens da história oficial.

A memória é a teia que une as diversas narrativas, que "tem o poder para manter vivas as coisas mortas" como uma das personagens comenta, pois "tudo depende da memória". ${ }^{10 *}$ No entanto, é imprescindível levar em consideração, como pondera Marie Ursule, que tanto os esquecimentos quanto as lembranças, são aspectos constitutivos do mesmo processo. ${ }^{1 *}$ Mais tarde, é Eula, bisneta de Bola, que revela as artimanhas da memória ao constatar que nada, de fato, muda: "A história abre e fecha, Mamãe. Estava lendo um livro outro dia sobre o século dezenove e parecia que eu estava lendo algo sobre o presente. Acho que nos esquecemos de quem somos. Nada está mudando, nós apenas nos esquecemos". ${ }^{12 *} \mathrm{Na}$ carta que escreve do Canadá para sua mãe em Culebra Bay, Eula fala do esquecimento histórico e de como a memória, em vez de servir como reparação, está fadada a ser também esquecimento e repetição. Eula vê o presente pelas lentes do passado, mas constata sua perene presença. A memória da escravidão histórica, o sacrifício/delito cometido por Marie Ursule, os rastros deixados pelas geraçôes que os antecederam parecem não serem capazes de mudar o rumo da história ou de ofertar uma redenção porque o esquecimento, inerente ao trabalho de memória, apaga os traços memoriais ao mesmo tempo em que esses são trilhados. No entanto, o ato de narrar, de escrever a carta para uma mãe já morta assinala

\footnotetext{
${ }^{9}$ No original: "centuries are forgetful places".

${ }^{10}$ No original: "power to keep dead things alive. Everything depends on memory."

${ }^{11}$ No original: "she had taken account of forgetfulness and remembrance".

${ }^{12}$ No original: "History opens and closes, Mama. I was reading a book the other day about the nineteenth century and it seemed like reading about now. I think we forget who we are. Nothing is changing, it is just that we are forgetting."
}

* (Ibidem: 115.)

* (Ibidem: 19.) 
sua profunda vinculação com o passado, sua urgente necessidade do rememorar e a impossibilidade de esquecer. "Estou escrevendo para ninguém", afirma Eula.* Ao mesmo tempo em que nega a utilidade da escrita, seu imperioso ímpeto de escrever se alia a seu medo do esquecimento. As palavras grafadas servem, assim, como ato de rememoração e preservação da memória, um possível antídoto contra o esquecimento iminente e inevitável, apesar do paradoxo de constatar que quanto mais escreve, mais se esquece. ${ }^{13}$

A narrativa conclui com a estória da segunda Bola, filha de Eula, enviada para Culebra Bay para ser criada pela avó materna, que a menina acredita ser sua máe. Seu nome já aponta para o papel cíclico desta saga que liga as duas personagens de mesma alcunha (a filha de Marie Ursule e a filha de Eula), que permanecem em Culebra Bay, diferentemente dos demais herdeiros, espalhados pelo mundo. Igualmente significativa é a escolha por reencenar o título desses capítulos - At the Full and Change of the Moon - que ao reverberar o título do livro náo apenas reproduz uma imagem especular, mas também retoma a temática e o processo contínuo de uma memória espiralar. Em um processo emblemático de ruptura e retorno, a nova Bola se torna ao final do romance o receptáculo das memórias de todos os antepassados. Embora aconteçam em diferentes segmentos cronológicos da espiral, o nascimento das duas Bolas inaugura a possibilidade simbólica de recuperação e restauração da memória. No entanto, há, desde a carta de Eula à mãe, um certo receio do poder reparador da memória a ser transmitida a essa segunda Bola. Com presságio de mau agouro ao saber que a mãe havia conferido à filha o nome da matriarca, Eula pede que não a "sobrecarregue com uma memória que não é dela". ${ }^{14 *} \mathrm{E}$ é, de fato, tanta estória, tanta memória que faz com que essa segunda Bola sucumba ao oneroso fardo que lhe é conferido: "Nossa mãe disse que eu tinha uma boa memória e que ela me daria pequenas coisas para me lembrar por ela. Estou cheia das memórias dela". ${ }^{15 *}$ Enlouquecida só lhe resta assumir o destino que lhe fora traçado, mantendo os rituais diários mesmo após a morte da mãe/avó. Os rastros do passado ainda trazem até ela a imagem fantasmagórica

\footnotetext{
13 "I'm forgetting you even as I write this letter. The more I write the more I forget" (Ibidem: 236).

${ }^{14}$ No original: "Don't saddle her with a memory that's not hers".

${ }^{15}$ No original: "Our mother said that I had a good memory and she would give me little things to remember for her. I am full of memories for her".
} 
da tataravó morta, Marie Ursule, aquela cujo delito transgressor garantiu a sobrevivência das geraçóes que a seguiram. Se para Derrida* a loucura está inerentemente ligada à perda da memória pela perda da linguagem e à assimilação da língua do outro, aqui a loucura se associa à hipermnésia, ao excesso da memória herdada, e funciona como um fardo maldito a ser penosamente carregado.

O romance de Brand coloca em relevo uma narrativa que atravessa espaços temporais e perspectivas variadas, oferecendo um relato da memória cujos fios são unidos pela imagem transgressora da matriarca, Maria Ursule, um relato que tenta recuperar as estórias passadas ao mesmo tempo em que reflete também sobre o papel dúbio da memória que não pode se esquivar do esquecimento. Ao esboçar um traçado de uma memória retalhada, suas personagens transitam por espaços imaginários (e imaginados), construídos pelo esforço coletivo de preservação de memórias lacunares e intervalares. Se, por um lado, esses vestígios memoriais só podem ser concebido pela ação coletiva, razão pela qual a primeira Bola optar por gerar toda uma linhagem de sucessores para através deles preservar a memória que até entâo somente ela acolhia, o fim aparentemente trágico da segunda Bola parece apontar para a fragilidade desta memória coletiva construída sob os pilares das experiências e das relembranças individuais.

Ruínas da memória

When the letters are memory we make whole words. ${ }^{*}$

Publicado vinte anos após Beloved (1988), A Mercy (2008), de Toni Morrison, retoma a temática candente que fez o primeiro romance um marco nas narrativas contemporâneas que tratam a espinhosa fenda histórica da escravidão, assim como ocorre com At the Full and Change of the Moon. Como na narrativa de Brand, esta se ocupa de um relato igualmente trágico que tem em seu bojo também um crime, embora esse somente possa que ser compreendido após termos percorrido as memórias de cada um dos personagens centrais. Diferentemente da narrativa de Brand, cujo tropo da memória aliada a do deslocamento humano ocupa espaço privilegiado, A Mercy enfoca, em especial, o ato derradeiro de contar estórias, como aponta a epígrafe escolhida para abrir esta seção: "quando as letras se tornam memória nós formamos palavras intei-
* (DERRIDA, Jacques. O monolinguismo do outro ou a prótese de origem. Trad. Fernanda Bernardo. Porto: Campo das Letras, 2001.)

* (MORRISON, Toni. A Mercy. New York: Alfred A. Knopf, 2008: 12.) 
ras".* O significado dessa enigmática sentença, proferida por Florens, uma das personagens centrais do romance, somente é revelado ao final quando, entáo, tomamos conhecimento da natureza do crime ao qual alude na abertura do romance: "Não tenha medo. Minha narração não vai machucar você, apesar do que eu fiz, e eu prometo ficar deitada no escuro quietinha - chorando talvez ou ocasionalmente vendo o sangue mais uma vez". ${ }^{16 *}$

Florens, assim como ocorre com a narrativa de Eula através da carta à mãe, é a única personagem que relata sua experiência em primeira pessoa. Talvez porque, como Eula, ela detenha os fragmentos mais emblemáticos para entendermos a saga de um grupo de mulheres nos Estados Unidos no século dezessete que aos poucos se descortinará nessa narrativa aparentemente fragmentada. " $\mathrm{O}$ começo", nos informa Florens na abertura do romance, "começa com os sapatos" ${ }^{17}$ e a eles retornaremos ao final do romance. A constante referência aos sapatos no relato vertiginoso de Florens serve de motivo para expor o trabalho da memória como repositório de experiências de trauma. Os sapatos de salto alto que quando criança insistia em usar são índices da experiência traumática de abandono pela mãe, episódio que será reencenado repetidamente ao longo da narrativa, como marca daquilo que foi recalcado e insiste em retornar fantasmagoricamente.

As demais estórias são relatadas por um/a narrador/a em terceira pessoa que focaliza separadamente em cada um dos personagens. Nesse sentido, a narrativa de Morrison em muito se assemelha à de Brand, expondo as estórias individuais, contando os mesmos episódios sob perspectivas diferentes e elaborando um texto que se constrói de fragmentos de memórias, de resíduos e pistas deixadas ao longo da narrativa.

O romance se delineia em torno de um grupo de personagens sem laços consanguíneos, mas que forma uma estranha e variada família, todos de certa forma órfãos sem outros vínculos a não ser aqueles estabelecidos no seio desse grupo: "Enquanto o Senhor estava vivo era fácil encobrir a verdade: eles não eram uma família - nem mesmo um grupo com ideias parecidas. Eles eram órfãos,

\footnotetext{
${ }^{16}$ Todas as traduçôes do romance são de minha autoria. No original: "Don't be afraid. My telling won't hurt you in spite of what I have done and I promise to lie quietly in the dark - weeping perhaps or occasionally seeing the blood once more".

${ }^{17}$ No original: "The beginning begins with the shoes".
} 
cada um deles". ${ }^{18 *}$ Jacob Vaark, o Senhor a quem se refere a citação, é o dono da fazenda na qual vive com sua esposa Rebekka Vaark, que mandou buscar na Inglaterra em troca pelo pagamento dos débitos de seus pais; Lina, uma indígena cuja tribo havia sido dizimada, e que é comprada para auxiliar nos afazeres da fazenda; Sorrow, uma criança abandonada, com problemas mentais, que ele acolhe; e Florens, a escrava de mãe angolana que lhe foi outorgada ainda em criança em pagamento a um débito. É pela perspectiva dessas personagens tão diversas que irrompem as memórias mais recônditas que juntas formam a tessitura da narrativa e revelam a tragicidade de cada uma das estórias.

A marca que essas personagens carregam e que compartilham é uma experiência eivada pela condição marginal e pela orfandade em diversos níveis, desde Jacob, órfão que sozinho constrói seu refugio, até Florens cuja estória de abandono traça seu destino. Talvez seja essa condição de sujeitos despossuídos e desamparados que faz com que se agreguem uns aos outros e façam do resgate de suas memórias uma estratégia de compensação. Não há, nesse contexto, a possibilidade de esquecimento que obsevamos no romance de Brand, apenas o excesso da rememoração que não encontra outro refúgio senão pela narração, como o "memorial obsessivo", sobre o qual nos fala Bhabha, daquilo que foi expurgado, mas retorna (como um unheimlich) incessantemente para clamar seu espaço com relação ao sujeito e a história.*

Se podemos, por um lado, afirmar que essas personagens demarcam espaços de exclusão por questóes de gênero, raça/etnicidade e outros fatores (insanidade, por exemplo), por outro, podemos destacar questóes históricas que perpassam de forma contundente toda a narrativa como forma de denúncia: o extermínio da população nativa, através da história de Lina, e, principalmente, o tráfico de escravos, que é recontado pela vivência de Florens, mas que também é relatado como sendo o suporte econômico que garante a riqueza da América. Nem mesmo Jacob que afirma que o tráfico de escravo é o mais infame e degradante dos negócios ${ }^{19}$ consegue se manter isento. Sua riqueza repentina, proveniente do comércio de rum, se sustenta justamente pelo tráfico de escravos para o

\footnotetext{
${ }^{18}$ No original: "As long as Sir was alive it was easy to veil the truth: that they were not a family - not even a like-minded group. They were orphans each and all".

19 "the most wretched business" (MORRISON, Toni. A Mercy. New York: Alfred A. Knopf, 2008: 29); "it's a degraded business" (Ibidem: 33).
}

* (Ibidem: 55.)

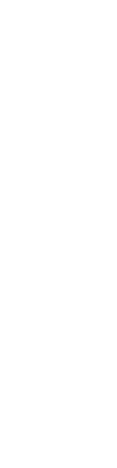

(BHABHA, Homi. O local da cultura. Trad. Myriam Ávila, Eliana Reis e Gláucia Gonçalves. Belo Horizonte: Editora UFMG, 2007: 274.) 
Caribe, aonde são levados para trabalhar nas plantaçóes. Deriva daí uma questão ética que não escapa à incisiva crítica de Morrison. Embora para Jacob esse seja um negócio aceitável, já que não necessita diretamente comercializar "carne humana" na América, seu comércio alimenta todo um mecanismo de exploração humana que sai da África e passa pelo Caribe em direção às Américas. Não é, pois, surpreendente que a morte de Jacob se revista de um significado simbólico, pois ele morre ao entrar na casa construída com o sustento desse comércio, tomado pela varíola que havia vitimizado tantos indígenas e africanos. A catástrofe anunciada do desfecho narrativo já havia sido aventada quando todos os filhos do casal vão aos poucos morrendo ainda na infância, incluindo Patrician, a filha de cinco anos do casal, a única que havia até então sobrevivido. Estão, assim, fadados a não deixar nenhum vestígio de sua existência, nenhum rastro que possa ser trilhado por geraçôes futuras. Essa impossibilidade de preservação de uma herança familiar, como ocorre também no romance de Brand, se reveste de um aspecto trágico na medida em que a pulsão basilar pela continuidade é negada, somente restando ruínas, dejetos e detritos daquilo que um dia foi um sonho, como a casa que Jacob nunca termina de construir e permanece desabitada, ao não ser pela visita constante de Florens, como veremos a seguir.

Se At the Full and Change of the Moon são as personagens que seguem os rastros para reconstruírem o passado e a história de Marie Ursule e Bola, em A Mercy são os leitores que seguem as pistas deixadas pelas narrativas das várias personagens procurando desvendar aos poucos os trilhamentos deixados. Quando o romance se inicia acompanhamos Florens em seu percurso à procura do ferreiro que havia construído os portóes da nova casa e por quem estava perdidamente apaixonada. Sua viagem de busca é uma tentativa de salvar Rebekka que padece da mesma enfermidade que o marido. Por onde passa Florens deixa suas pistas e marcas, mas também vai paradoxalmente trilhando os rastros do passado e revelando seu trauma mais profundo ocasionado pelo episódio no qual a mãe pede a Jacob, que deveria escolher um escravo como pagamento de débito do fazendeiro português, que não a leve pois tem um filho pequeno para amamentar, mas que, em troca, leve a filha pequena Florens: "O Senhor dizendo que vai levar a mulher e a menina, mas não o bebê, e é o fim do débito. A minha mãe implora não. Ela ainda amamenta o bebê. Leve a menina, ela diz, minha filha, 
ela diz. Eu. Eu". ${ }^{20 *}$ É essa cena, repetida ininterruptamente em sua memória e em seu relato que permanece como rastro daquilo que não pode ser apagado e retorna incessantemente, narrado sempre com as mesmas referências: os sapatos; o filho da mãe a quem, na visão de Florens, ela elege em detrimento de sua presença; a voz da mãe que tenta, sem sucesso, lhe dizer algo: "mães que amamentam bebês vorazes me amedrontam. Eu sei como seus olhos se movem quando elas escolhem. Como elas levantam eles para me dirigir um olhar duro, dizendo algo que não posso escutar. Dizendo algo importante, mas segurando a máo do menino pequeno". ${ }^{21 *}$ Florens insiste em nos dizer que ela tem uma memória, ${ }^{22}$ quer essa seja do abandono pela mãe ou da marca deixada pelo ferreiro em seu corpo - imagens essas aliadas a sua perene necessidade de afeto e reconhecimento.

Cada uma das personagens femininas é marcada pela memória ou pela ausência dela de maneiras diferentes. Para Rebekka, sua enfermidade e o delírio dela proveniente a leva aos espaços mais profundos e recônditos da memória onde encontra não apenas a lembrança reprimida da filha morta, mas também os momentos de irmandade que compartilhou com outras mulheres durante o traslado da Inglaterra para os Estados Unidos para desposar Jacob. São memórias abalizadas pelo selo da posição das mulheres no século 18 , colocadas à mercê da estrutura patriarcal e para um tráfico no qual seus corpos são a moeda de troca, como já relatou a antropóloga Gayle Rubin. ${ }^{23 *}$

Lina, por sua vez, carrega não somente a memória cada vez mais lacunar de seus antepassados indígenas e de sua tradição e cultura, mas também o que aprendeu com o convívio com os "Europes": "Confiando na memória e seus recursos, ela juntou os rituais negligenciados, misturou a medicina europeia com a nativa, escri-

\footnotetext{
${ }^{20}$ No original: "Sir saying he will take instead the woman and the girl, not the baby boy and the debt is gone. A minha mäe begs no. Her baby boy is still at her breast. Take the girl, she says, my daughter, she says. Me. Me".

${ }^{21}$ No original: "mothers nursing greedy babies scare me. I know how their eyes go when they choose. How they raise them to look at me hard, saying something I cannot hear. Saying something important to me, but holding the little boy's hand".

22 "But I have a memory" (MORRISON, Toni. A Mercy. New York: Alfred A. Knopf, 2008: 64).

${ }^{23}$ Ver a discussão que empreendo sobre esse tráfico de mulheres no romance Desmundo (ALMEIDA, Sandra Regina Goulart Almeida. Corpo e escrita: imaginários literários. Revista da Universidade Federal de Minas Gerais v.19, 2012: 92-111.)
}

* (MORRISON, Toni. A Mercy. New York: Alfred A. Knopf, 2008: 13.)

* (Ibidem: 14.)

* (RUBIN, Gayle. The Traffic in Women: Notes on the "Political Economy of Sex". In: REITER, Rayna (ed.). Toward an Anthropology of Women. New York: Monthly Review, 1975.) 
* (MORRISON, Toni. A Mercy. New York: Alfred A. Knopf, 2008: 46.)

* (Ibidem: 48.)

* (Ibidem: 12.)

* (Ibidem: 140.)

tura com tradição, e se recordou ou inventou o significado secreto das coisas". ${ }^{24 *}$ Não podendo mais se apoiar numa memória que não foge ao inerente esquecimento, Lina não tem outra alternativa a não ser fazer de sua memória um espaço híbrido que coaduna as experiências herdadas e aquelas aprendidas no contato com o colonizador. Sua é também uma memória de violência não apenas nas mãos do colonizado, mas também nas mãos do homem que a violenta e espanca repetidamente, marcando sua marginalização pelo gênero e pela etnicidade.

Somente Sorrow (cujo nome significa apropriadamente "sofrimento") permanece ilesa aos efeitos da memória, já que ela "não tinha nenhuma memória de sua vida passada com exceção de ter sido puxada para a terra firme por baleias". ${ }^{25 *}$ Essa condição, no entanto, somente é possível pela situação de total exclusão de Sorrow e da impossibilidade de interação significativa com as demais. Sua vivência do presente e sua quase total desconsideração por aquilo que poderia ser interdito é, assim, levada ao extremo.

Mas é, sem dúvida, Florens o epítome da rememoração que em Beloved é assumido por Sethe. Ao final entendemos o significado das palavras proferidas ao início: "quando as letras se tornam memória nós formamos palavras inteiras".* É esse o rastro deixado por Florens em meio às ruínas da casa grande da fazenda, inacabada após a morte de Jacob. Por meio de sua própria narração descobrimos que Florens, ao ser rejeitada pelo ferreiro, em um episódio que reencena seu afastamento traumático da mãe, o ataca brutalmente. É para o ferreiro (dado como morto), objeto de desejo que se torna repulsa (na presença típica do unheimlich), que a estória é contada e a memória, preservada. Agora é uma Florens conduzida à insanidade pelo ato hediondo perpetrado e pela impossibilidade de aceitá-lo que escreve sua estória usando um prego com o qual desenha palavras indecifráveis nas paredes da casa inacabada e abandonada, na esperança de que "esta palavras cuidadosas, fechadas e abertas, vão falar por elas mesmas". ${ }^{26 *}$ A escrita da parede e do chão no espaço em ruína é uma escrita da perda, mas também

\footnotetext{
${ }^{24}$ No original: "Relying on memory and her own resources, she cobbled together neglected rites, merged Europe medicine with native, scripture with lore, and recalled or invented the hidden meaning of things".

${ }^{25}$ No original: "still had no memory of her past life except being dragged ashore by whales".

${ }^{26}$ No original: "these careful words, closed up and wide open, will talk to themselves".
} 
da memória, da recusa do esquecimento, um trabalho de rememoração e escrita; "Não há mais espaço neste quarto. Essas palavras cobrem o chão [...] O que vou fazer com minhas noites quando a estória acabar?". ${ }^{27 *}$

Significativamente, a narrativa termina com a fala da mãe, a voz que Florens náo consegue ouvir, os rastros que não consegue seguir, o traço do outro que ela não pode escutar. A mãe explica que jamais a abandonou e que foi com enorme sofrimento que cometeu um ato de misericórdia - em referência ao título do romance, A mercy - ao implorar a Jacob que a tirasse de um futuro incerto em meio à escravidão e ao abuso sexual que por certo sofreria nas mãos do comerciante de escravos à quem pertencem: "Foi um milagre. Concedido por Deus. Foi uma misericórdia. Oferecida por um humano. Fiquei de joelhos. No pó onde meu coração vai ficar cada noite e dia até você entender o que eu sei e anseio para contar para você: [...] dar o controle de você mesma para outro é uma coisa perversa. Meu amor. Escute a tua mãe". ${ }^{28 *} \mathrm{O}$ que a mãe teria a dizer a Florens, que pode ser tarde demais, é a importância de ter autoridade sobre si mesma, de não se deixar ser controlada ou dominada por outros. No entanto, não há menção na narrativa de que esse arquivo das memórias da mãe tivesse um dia chegado a Florens. A ela, bem como aos demais personagens, só resta a ruína e os cacos do passado que não podem jamais ser reconstruídos, a não ser como memória, nem mesmo depois que Rebekka se recupera, agarrando-se inutilmente à rígida religião que um dia criticara tão ferrenhamente, tornando-se rancorosa e intolerante.

O romance de Morrison ao enveredar pelos caminhos da memória individual resgatando os traumas gerados em consequência da exploração humana, em um passado não tão longínquo que possa nos apaziguar, coloca em cena uma reflexáo que nos leva a examinar o processo de narração dessa memória. Se, por um lado, é essa a forma de Florens se evadir do presente, que é demasiadamente trágico e aterrador para ser suportado, por outro, torna-a paralisada, impedindo-a de assumir o que sua mãe queria para si,

\footnotetext{
${ }^{27}$ No original: "There is no more room in this room. These words cover the floor [...] What will I do with my nights when the telling stops?"

${ }^{28}$ No original: "It was not a miracle. Bestowed by God. It was a mercy. Offered by a human. I stayed on my knees. In the dust where my heart will remain each night and every day until you understand what I know and long to tell you: [...] to give dominion of yourself to another is a wicked thing. Oh Florens. My love. Hear a tua máe".
} 
isto é, uma forma de agenciamento e controle. Florens continua, mesmo ao final, refém do desejo do outro. O fim a ela reservado - a loucura -, como também ocorre com a segunda Bola, faz ruir qualquer pretensa em relação ao poder edificante da rememoração e do resgate de rastros deixados pelos outros para serem seguidos, demarcando a impossibilidade de continuidade da ancestralidade. Alguma redenção somente parece possível pelo relato deixado por Florens, que marca de forma decisiva, o momento histórico e trágico da história das Américas e do Caribe que Morrison delineia com tanta perspicácia.

\section{Coda: escritas da rememoração}

Ambos os romances aqui analisados operam uma escavação profunda por meio de ruínas da história das Américas, especificamente do Canadá, dos Estados Unidos, e do Caribe como espaço indelével da passagem do meio na rota infame dos do tráfico de africanos ao longo da história. Delineiam, assim, uma crítica ao processo histórico da escravidão e da colonização que marcaram de forma contundente a exploração humana, não apenas dos povos africanos, mas também dos indígenas, como mostra Morrison. Marcam ainda o espaço de narrativas da rememoração que se filiam à linhagem e à herança feminina que não cessa de se ocupar de vestígios memoriais, especialmente pela tradução do legado materno.

Como escritas da perda, no dizer de Ginzburg, mas também como escritas da rememoração e espaços de ruínas apontam para a condição de ilegalidade e clandestinidade desses relatos que não sobrevivem a não ser por meio de rastros e vestígios, deixados ao léu, aparentemente sem intencionalidade. Quando a intenção existe, como no caso da primeira Bola e mesmo de Florens, acaba por ser minada, pois a presença da memória, como aprendemos, aponta insistentemente para sua ausência e sua excrescência leva à loucura. Nessa viagem de busca, mas também de aprendizado, quer seja pelo deslocamento para várias partes do mundo (como as dos descendentes de Bola), ou com uma missão de salvamento (como a de Florens) seguimos rastros que são constantemente apagados, deixando entrever apenas pistas e marcas que nos levam ao exercício de desvendar um mistério, um enigma ou uma trajetória.

Se em At the Full and Change of the Moon esse trabalho de reconstrução e resgate da memória é feito aos moldes de um arqueó- 
logo, que procura registrar os resíduos do passado para reconstruir a história, em $A$ Mercy é a tarefa do detetive que esmiúça as pistas em busca da solução de um crime inominável que recebe destaque. Em ambos os casos a topografia dos traços e sua inerente fantasmagoria fulguram insistentemente como espaços de uma memória que não pode senão ser ruína e apagamento. É essa inquietante percepção que nos acompanha ao final dos romances.

A posição que nos convém nessa jornada como leitores, e que parece ser demandada pelas inquietantes narrativas, como nos lembra Spivak na esteira de Derrida, é a de um aprendizado contínuo de respeito ao traço do outro, uma acolhida aos rastros desses sujeitos clandestinos e uma rejeição ao impulso de apagamento ao qual estão continuamente sujeitos.

Sandra Regina Goulart Almeida é Professora Titular da Faculdade de Letras da Universidade Federal de Minas Gerais. É Mestre e Doutora pela Universidade da Carolina do Norte, Estados Unidos, com Pós-doutorado em Literatura Comparada pela Universidade Columbia. É pesquisadora do CNPq e da FAPEMIG e desenvolve pesquisa na área de crítica literária feminista, estudos de gênero, estudos da diáspora, literaturas contemporâneas de língua inglesa e literatura comparada. Tem artigos publicados em revistas nacionais e estrangeiras. Coeditou os livros Perspectivas Transnacionais (2003), Brasil-Canadá: Olhares Diversos (2006), Mobilidades culturais: atentes e processos (2009), Migraçöes teóricas, interlocuçôes culturais: estudos comparados (Brasil/Canadá) (2009), Mobilidades Culturais: agentes e processos (2005).E-mail: <srga@ufmg.br>. 